\title{
Business analysis of the financial support for organic production in Montenegro technological and organizational aspects
}

\author{
Boban Melović1,*, Vladimir Đurišić ${ }^{1}$ and Sunčica Rogić $^{1}$ \\ ${ }^{1}$ Faculty of Economics, University of Montenegro, 81000, Podgorica, Montenegro
}

\begin{abstract}
This paper is exploring the importance of financial support for the development of organic production in Montenegro, based both on organizational and technological aspect. Empirical research as the base of this paper treats problems of financing this activity, the results showed that direct positive correlation exists between financing conditions and level of development of organic production, especially taking into account the use of contemporary technologies. Additionally, this is first field research of financing organic producers in Montenegro. The sample covered $18.6 \%$ of the total number of producers. One of the aims of this research is comparative analysis of financial support of international funds on one side and commercial banks on the other side. Namely, in modern business conditions imply the use of advanced technologies that require significant financial resources, therefore, financing conditions represent a critical factor of development of this area in Montenegro.
\end{abstract}

\section{Introduction}

In the last five years, focus of scientific and professional research is redirected from financing agricultural production in general, to the problem of financing organic production [1-4]. A special focus is being set on the technological and organizational aspect of the organic production. The cause is in fact that organic production market record annual growth rates over $10 \%$. Total value of organic products increased from 11 billion euros in 2000 to 63 billion euros in 2013 in the European $[5,12]$. This period has characterized bigger consumption then production within EU countries, which created an opportunity for candidate countries, like Serbia or Montenegro, have space to place their own products in this international market. Researching this area, it simply comes to conclusion that organic producers worldwide are being faced with similar problems. Research published by United Nations shows current problems of producers in Africa, where the problem of financing is being recognized as the leading one. Despite growing market and positive evolution in pricing policy of organic producers, existing literature and empirical research shows that organic producers have insufficient access to financial funds, especially in the domain of certification, organic production, research and the purchase of necessary equipment. For example, research conducted by Mala and Maly showed that some of the implementation of

${ }^{*}$ Corresponding author: bobanm@ac.me 
the organic production technology is negatively affected primarily by the rising age of farmers and that large farms do not have a tendency to make the transition to the organic production $[6,18]$. Besides that, limited credit mechanisms and insufficient capacity of commercial banks represent the most significant problems in the field of financing this production in Africa [7]. Research conducted in Czech Republic also shows the need of more favourable funding practice of organic production, with an ongoing objective to keep the rural population in these areas [8]. Group of authors recognized the role of tax policy in the function of developing organic production in Serbia. Namely, except direct financing, through different credit lines, tax policy could have significant place in implementation of long-term development policies in organic production area [9]. Certain tax reliefs would stimulated more productive organic production, and therefore, European Union market would be more accessible. Considering similar level of development of this branch, proposed implementation measures would have had positive effects on improving organic production in Montenegro. Previous research of organic production problems in the world showed that this developing aspect of agriculture is not used in a sufficient extent considering the production-economic performance and natural and ecological resources. Possibility of significantly higher production of organic food is one of potential factor of competitiveness of agricultural production of Montenegro in international exchange [10]. In accordance with objects and purpose of this research, three hypotheses have been formulated:

H1: Favourable financing conditions are in direct positive correlation with development of organic production in Montenegro.

H2: Non-adapted offer of commercial banks represents a limiting factor for the improvement of organic production in Montenegro.

H3: International financing projects represent the base of financial support to organic production in Montenegro.

Hypotheses will be tested on the basis of empirical research conducted in the form of interviews as well as presented theoretical conclusions and situation analysis in the organic production sector.

\section{Situation analysis}

Organic production appeared as a reaction to ecological degradation and increased presence of unhealthy food. Current situation in global agriculture shows an increasing trend of demand for organic food, especially in industrial developed countries [11, 13, 14]. The cause is recognized in developed consciousness about importance of organic food for health and higher purchasing power of consumers. Development of organic food in Montenegro starts at the beginning of this century, when more important movements are noticed after 2010, after getting a candidate status for being part of European Union. Starting negotiations about access to EU opens possibilities for using Union funds, which support the technological advancement of agriculture, and with it - organic production. Beside that organic productions take only $1 \%$ of total world food market, even though it becomes more demanded, therefore, its' participation is even more important in worlds trade flows. Market of developed countries is characterized by low saturation of organic productions [15, 17], so Montenegro, as a country with preserved land has a real potential to improve this segment of agriculture and improve its' position in international trade. In 2010, Europe had 8,2 million hectares of organic agricultural land, which accounts $25 \%$ of total world land of organic production, and the average share of organic surfaces by member state of EU was 4,7\%. Leading European countries in organic production surfaces are Liechtenstein $(29,8 \%)$, Austria (15,9\%), Sweden $(10,6 \%)$, Switzerland $(10,8 \%)$ and Estonia $(10,5 \%)$. Leaders on the organic food market are Denmark, Austria and Switzerland where the share of organic food in the market is above $5 \%$. Current organic production expressed in hectares in Montenegro is on the level of 3.000, 
in per cent, organic production spreads on less than $1 \%$ of total arable surface. This indicator is so far below average of EU, so with the access to EU we expect significant improvement of this sector. To their benefit goes the fact that the membership in EU makes the possibility for the approach of funds for development of rural areas. In addition to the obvious progress that is expected in the technological sense, through access to funds, it is realistic to expect improvement of organizational performances of the producers, both through engagement and consulting of professional staff, as well as through the development of operations on foreign markets.

Organic production is in the direct positive correlation with economic and social development, because it is recognized that crossing to organic agriculture opens new work places on farms and contributes to slowing down of negative trend of depopulation and leaving rural areas, which currently represents big challenge for Montenegro. In 2017, Montenegro has 285 registered producers of organic food. The largest number of producers is on the North of the country, even $80 \%$, when in the South regions, there are only 4 registered producers. In structure of organic producers, the most dominant are breeders of plums, apples and pears and there are 153 of them. In the last 2 years, the growth of interest for production of raspberries is noticeable, so there currently 22 producers. Devastating data is that there are only 2 producers of olives, considering geographical position and comparative advantages of Montenegro for this segment.

Existing legal framework made conditions for giving a support to organic production through measures of agriculture policy, especially to groups of measures for sustainable management of natural resources, where organic production has special place. Until 2009, the support was given to producers to adapt the technology requirements of organic production (up to 3000 euros), for the certification costs (up to $50 \%$ of the total project value) and for improving capacity for development of organic agriculture, education and promotion. For these purposes 120.000 euros were defined in 2006, 150.000 euros in 2007, 165.000 in 2008 and 165.000 in 2009. By 2009, a new measure is implemented for production improvement. Support was in a form of direct payments by hectare or by conditional piece of livestock, as it is as follows [16]: for crop cultivation and cultivation of medicinal herbs 150 euros/ha, for vegetables, perennial plantings and seed and planting material 250 euros/ha, by piece of livestock 50 euros, and by hive 30 euros.

Beside this type of support, in the aim of improving product quality, through measures of strengthening competitiveness of agriculture, the support is given for transforming agricultural producers into organic agriculture and refers to costs of introduction of standards, certification and participation in the quality scheme and is given for the first five years since inclusion. That support had a form of standardized payment and in 2011 it accounted for a maximum of 1.000 euros.

\section{Empirical research methods}

For the purpose of this paper an empirical research has been conducted on a sample of 53 respondents. The sample is representative and represents $18.6 \%$ of the total population. The sample includes organic producers from all cities of Montenegro, in proportion to their participation in the total number of organic producers, therefore, the sample type is quota sample. The research has been conducted in the third quarter of 2017, and the base of the research was the survey of 14 questions. The survey has been conducted in a personal interview and though the phone. The survey wasn't conducted online and through email, considering the respondents structure and the level of computer literacy, in order to achieve greater number of valid surveys. The conclusions from the collected data were derived using the content analysis method. Descriptive statistics was used to objectively interpret the data, and allowed their visualization through the process of graphical presentation of data. 


\section{Results and discussion}

Considering the location of organic producers in Montenegro, as much as $70 \%$ of the sample is from the north of Montenegro, whose dominant activity is the production of cereals, apples and plums. In addition, $20 \%$ of the respondents are from the central region, with the largest share of producers of honey, plums and figs. The remaining $10 \%$ of the respondents are from the southern region, with the main activity of olive and wild pomegranate cultivation. As for the age structure, $50.9 \%$ of the producers are aged from 31 to $40-30.2 \%$ of the respondents are between the ages of 41 and $50-15.1 \%$ are older than 50 years. A devastating fact is that very few people under the age of 30 are engaged in organic production in Montenegro, and only $3.8 \%$ of them are included in the sample. The majority of respondents $(79.2 \%)$ have been engaged in organic production for more than five years, but during the interview they pointed out that at the same time this period was not longer than ten years. This is brought about by the recognition of the importance of organic production by the government. Namely, one of the basic motives for redirecting activities towards organic production is reflected in the creation of programs intended for financial support by both the state and foreign funds.

The first significant programs supporting the development of organic production in Montenegro relate to 2011 and 2013, and the ability to use the funds from the Danida (Donation of the Danmark kingdom through the project: „The program of organic production development in Montenegro") and Midas (Project of institutional development and strenghtening the agricultural production - World Bank) program. With the growing awareness of the population about the benefits of these projects, their interest in organic production has increased, and the number of farmers who adjusted their activities to organic standards has grown. Unlike domestic commercial loans, which were current at the time, the funds received by this project were significantly more favourable in terms of interest rates, and an even greater advantage was seen in the part of grants which went up to $60 \%$. With this research, we have come to the conclusion that over $60 \%$ of organic producers have invested over 20,000 euros in this business, which has misled the misconception in our culture that organic production does not require significant financial resources. Namely, about $80 \%$ of the funds invested are aimed at purchasing the necessary machinery. Therefore, it can be concluded that Montenegrin producers are aware of the importance of modern technologies for gaining competitive advantage. Most of this investment was financed by the producers with a combination of own and credit funds, with favourable credit funds having a significantly higher share $(60 \%)$. The reason why none of the respondents stated that they have funded their production entirely from borrowed sources is found in the conditions for obtaining funds through the mentioned support programs. Precisely, the mentioned programs required their own participation in the investment of at least $30 \%$. Another reason justifying this conclusion is the fact that organic producers in Montenegro organize their activities dominantly within the household, and this activity is based on family business.

As for most family businesses, the main weakness is reflected in the lack of funding, which emphasizes the importance of favourable financing conditions. In addition, the engagement of professional staff poses as a challenge. Taking into account the collected data and the above mentioned analysis, it is concluded that the first defined hypothesis Favourable financing conditions are in direct positive correlation with the development of organic production in Montenegro, has been confirmed. Considering the fact that Montenegro is not yet a full member of the European Union, access to funds from funds intended for organic production is at a much lower level compared to European countries. In addition to funds from international funds and government support, producers are offered loans from commercial banks. The basic problem from the perspective of the producers is the conditions defined by the banks. The banking sector considers this activity to be highly risky, and therefore the offered offer is not adequately adapted to this target segment. Bid 
adherence is reflected in high effective interest rates, the absence of a grace period, and demanding security instruments. Namely, the interest rates for this sector ranged between 9 and $17 \%$ in the last four to five years, while loans from international funds, through the Investment and Development Fund of Montenegro, were approved at interest rates of 3 to $4.5 \%$.

In addition to the interest rate, a significant parameter of financial support to organic production is a grace period. More specifically, the Investment and Development Fund and the Ministry of Agriculture define a grace period depending on the specific activity the manufacturer deals with. Finally, demanding security instruments pose another obstacle to the financing through commercial banks, as manufacturers are asked for collateral, which the banks can easily market and sell, but the producers generally do not own such collaterals. In addition, commercial banks, as one of the primary criteria for granting loans, value the client's employment, and therefore, most organic producers (85\%) do not fulfil the conditions. Taking into account the current offer of commercial banks, as well as the results of the empirical research on the attitudes and perceptions of the banking offer, it can be concluded that the financing conditions of this sector are extremely unfavourable for organic producers. However, it would be wrong to understand that organic producers do not use loans from commercial banks, but they are opting for this source of financing only when the funds from international funds are not sufficient to complete the investment. In accordance with the above results, the second hypothesis - Non-adapted offer of commercial banks is a limiting factor for the improvement of organic production in Montenegro, is confirmed.

In addition to financial support, it is important to emphasize that the poor purchasing power of consumers is another limiting factor in the development of this activity. Lower prices for organic products in Montenegro, compared to EU countries, are due to lower purchasing power. However, with potential improvements in living standards, organic producers would be able to charge higher prices, which would, in the end, create an opportunity for funding by currently unattractive sources. Therefore, we conclude that with the growth of purchasing power, the ability of the producers to be financed at higher interest rates is also growing. In this survey, $91 \%$ of respondents indicated that they were beneficiaries of funds such as Danida, Midas and Ipard, which makes these projects the base of financial support for the development of organic production in Montenegro. Analysing the data collected by this research, we came to the information that the maximum amount of funds within the sample was 35.000 euros, i.e. that the users on average had $50 \%$ of the grant. As the main weaknesses of this method of financing, manufacturers emphasize: a complex process of application, as well as a long time interval from the moment of application to the grant of funds. On the other hand, the state played an important role in timely informing the public, so the producers had enough time to collect the necessary documentation for the application. This confirms the third hypothesis - International funding projects are the basis of financial support to organic production in Montenegro.

In addition to relying on international funding institutions, as well as waiting for state aid from the relevant ministry, we believe that a new financing model could be defined, which implies links with certain economic entities, in particular hotels and retail chains, in whose interest is to have organic products, therefore, financial support for producers would be mutually beneficial. In the function of faster and more favourable obtaining of credit funds from Montenegrin organic producers, awareness of the importance of insurance of the household should be developed. The devastating fact is that $88.6 \%$ of respondents do not insure their possessions, which often disqualifies them in the review process for the approval of funds by commercial banks, given the high level of risk. The low level of awareness about the importance of insurance in the agricultural sector is confirmed by the statistics of the Ministry of Agriculture of Montenegro, which shows that in 2012 only 2 agricultural producers secured their property, and in 2013 four producers. As already stated, with 
Montenegro's membership in the European Union, a greater access to funds that support the development of organic production is expected, which significantly determines the prospects for the development of this economic activity.

\section{References}

1. A. Bibler, Occupational Outlook Quarterly (Fall, 2010)

2. L. Conolly, National Organic Conference (2008)

3. I. Ljumović, B. Viduka, J. M. Cvijanović, Economics of Agriculture, 4 (2015)

4. E.C. Hough, W.T Nell, International Farm Management Congress (2003)

5. H. Willer, L. Kilcher, The World of Organic Agriculture - Statistics and Emerging Trends, 3 (2012)

6. Z. Malá, M. Malý, Agricultural Economics - Czech 59(1), 19-28 (2013)

7. UNCTAD, Financing Organic Agriculture in Africa: mapping the issues (2016)

8. J. Jánský, I. Živělová, P. Novák, Agricultural Economics - Czech 50, 394-399 (2004)

9. M. Kalentić, E. Stefanović, I. Simić, U. Maerz, Serbia organica (Beograd, 2014)

10. S. Oljača, Poljoprivredna tehnika, 61 (2008)

11. J. Čikić, Ž. Petrović, Poljoprivredni fakultet Novi Sad (2016)

12. H. Willer, The World of Organic Agriculture: Statistics and Emerging Trends (2013)

13. D. Pearson, Agribusiness Review, 9(8) (2001)

14. R. J. McRae, B. Frick, R. C. Martin, Canadian journal of plant science 87, 1037-1044 (2007)

15. V. Skrodzka, Management 21(2), 151-164 (2017)

16. Internal documentation of the Ministry of agriculture and rural development of Montenegro

17. L. Palšova, Procedia - Social and Behavioral Sciences 110, 520 - 529 (2014)

18. F. Sgroi, Sustainability 7, 947-961 (2015) 